\title{
Development of a Thermochemical Conversion Unit for Corn Residues
}

\author{
Greg M. CuBiO ${ }^{* 1}$, Andres M. TUATES Jr ${ }^{*}{ }^{\dagger}$, Earl LABITAD ${ }^{* 2}$, \\ Glenn B. PACLIJAN ${ }^{*}$, and Ofero A. CAPARINO ${ }^{2}$
}

(Received March 24, 2020)

\begin{abstract}
The utilization of corn residues as a potential biomass for thermochemical conversion was investigated. The general objective of the study was to design and develop a thermochemical conversion unit and evaluate its performance in terms of the production of bio-oil, bio-char and syngas. The developed thermochemical conversion unit comprises a hopper, modified worm drive, reactor, cyclones separator, and syngas condenser. Three kilograms of size-reduced corn cobs were loaded to the reactor, then subjected to thermochemical conversion varying the operating temperature (with and without heater) and three airflow rates. Results showed that the highest percentages of biochar, bio-oil and syngas collected using the developed machine were $24 \%$, $37 \%$ and $59 \%$. Biochar contained $34 \%$ of volatile combustible matter, $60 \%$ of fixed carbon and a heating value of $26.3 \mathrm{MJ} / \mathrm{kg}$. The thermochemical conversion unit has a waste to energy conversion efficiency that could reach as high as $91 \%$. To achieve the highest percent recoveries of bio-oil and syngas, the machine should be operated at an airflow of $84 \mathrm{~L} / \mathrm{s}$. On the other hand, to obtain the highest recovery of bio-char, the unit should be operated at lower airflow. The conduct of up-scaling of the developed thermochemical conversion unit, testing and evaluation under field condition, and perform financial analysis are recommended.
\end{abstract}

\section{Key Words}

Agricultural wastes, Thermochemical, Gasification, Corn cob, Corn by-products

\section{Introduction}

Crop residues are a valuable resource both in the field and as a potential biofuel. Crop residues are critical in protecting and maintaining our nation's valuable natural resource (soil and clean water). A wide range of agricultural residues (e.g., corn stover, straw, etc.) can produce secondgeneration biofuels. Such biofuels are generally considered sustainable as they use waste materials from food crop production and do not compete with food crops for land. Among the renewable energy sources, only biomass offers the possibility to produce liquid, carbon-neutral fuels ${ }^{1)}$. Some advantages of the biomass are a low-cost by-product in agriculture and forestry, low ash and sulfur contents, and no $\mathrm{CO}_{2}$ level increase in the atmosphere, since the biomass

$※ 1$ University of Science and Technology of Southern Philippines (USTP) Cagayan De Oro City

$※ 2$ Philippine Center for Postharvest Development and Mechanization (PHilMech)

CLSU Compound, Science City of Munoz, Nueva Ecija

※3 Xavier University - Ateneo de Cagayan Cagayan De Oro City

† Corresponding author: amtuates@yahoo.com consumed does not exceed the forest production ${ }^{2)}$.

During the torrefaction process, solid biomass is heated in the absence of or drastically reduced oxygen to a temperature of approx. $250-350^{\circ} \mathrm{C}$, leading to a loss of moisture and partial loss of the biomass's volatile matter ${ }^{3)}$. Pyrolysis and gasification are typically multi-step processes with many similar steps, including (1) feedstock preparation, (2) introduction of the feedstock into the reactor, (3) the pyrolytic decomposition or gasification reaction, and (4) separation and post-processing of the gases, oils (in the case of pyrolysis), solid char, and ash ${ }^{4}$.

Many studies ${ }^{5)} \sim$ 10) have examined the economics of corn stover supply for biofuel production. While these studies have focused on estimating the costs of harvesting corn stover as a whole, only a few studies have particularly emphasized examining the costs of supplying corn cobs as a potential feedstock using up-to-date harvesting technologies. Corn stover was identified by Environmental Protection Agency and United States Department of Agriculture as the third feedstock in importance to meet the annual mandate. Corn stover is expected to provide about 25\% of 
the total advanced biofuels supply. Due to high density and yields, the bulk of corn residue is expected to come from the Corn Belt ${ }^{11)}$.

As a result of considerable research, development, and pilot-scale demonstration work done during the past 25 years ${ }^{12}$, large-scale biomass gasifier technologies could be commercially ready within two or three years with concerted development efforts, but commercial-scale projects are needed to demonstrate viability. There is already the extensive worldwide commercial application of gasification of fossil fuels such as coal ${ }^{13}$. The experience being accumulated from these activities is relevant to the gasificationbased conversion of biomass. Biomass can be co-gasified with coal, which may offer some valuable synergies ${ }^{14)}$. Biomass is already being commercially co-gasified with coal today at one electricity-generating facility in the Netherlands, the 250 MWe Buggenum facilities ${ }^{15}$.

Torrefaction, gasification and pyrolysis have become the emerging technologies for converting biomass into energy from a different form of biofuels. Biofuels from these processes include combustible gases, bio-oil and bio-char. Bio-oil can be processed further into different hydrocarbon fuel by fractional distillation while bio-char is used for soil amendments and activated carbons. Bio-oil contains several functional groups including alcohols, aldehydes, carboxylic acids, esters, ethers, furans, ketones, phenols and sugars ${ }^{16}$. Combustible gases, commonly called syngas, can be used directly for engine fuels to produce electricity or be now utilized for the cookstove.

This study envisioned to develop these three thermochemical processes using corn residues and vary the operating conditions to allow the production of any desired primary output (i.e., syngas, bio-oil, or bio-char). It would be beneficial to develop a versatile system that can operate on pyrolysis mode, gasification or torrefaction. This is because farm operations throughout the year are variable. The need to produce carbon from biochar may be a priority for soil conditioning purposes while utilizing bio-oil and syngas for energy while, at some point, the farmer may need to produce bio-oil more than biochar and syngas. Since the three energy conversion products are dependent on operating conditions, one thermochemical conversion system that could accommodate such variations is economically significant.

This study focuses on corn residues since corn is the primary agricultural crop in the Northern Mindanao region with more than 50,000 ha of the plantation. Corn residues that include corn cobs and corn stalk constitute $50 \%$ (by weight) of the total agricultural wastes collectibles in Region $10^{17}$. With this study, it is expected that energy generation will be augmented using biomass-based power. Small to medium-scale farmers could utilize such technology to mechanize farming activities while producing soil conditioner from bio-char. The mechanization level could be increased due to the additional energy from corn residue. Once implemented, the conversion system could be retrofitted to accommodate any agricultural waste. The general objective of the study was to design, fabricate and evaluate the performance of a thermochemical energy conversion system for corn residues.

\section{Materials and Methods}

\subsection{Design consideration and preparation}

The thermochemical conversion unit design was based on the existing gasifier owned by the Department of Energy in the Philippines and the bench-scale fluidized pyrolizer developed within the Agricultural Research Service (ARS) of the United States Department of Agriculture (USDA). AutoCAD software was used to prepare the design, measurement of dimensions that served as a guide in the fabrication of the thermochemical conversion unit.

\subsection{Fabrication of thermochemical conversion unit}

The thermochemical conversion unit comprises the following components: motor, gearbox, hopper, conveyor, reactor, two cyclone separators and the syngas condenser (with four condenser canisters in series). The system components were fabricated using locally available materials in Cagayan De Oro City. It comprises the reactor vessel system and associated supplementary systems for air distribution, biomass feeding and entry, and vapor condensation for bio-oil recovery. Such design features are described in Table 1.

\subsection{Collection and preparation of samples}

Corn cobs (CC) samples used in the study were collected from Baungon, Bukidnon. Corn cobs were immediately placed in sacks after the shelling process, tied and stored inside the building while waiting for the succeeding processing operation. Since the corncobs were already air-dried in the field at a moisture content of 15\%, it was placed in a container for weighing prior to loading into the hopper.

\subsection{Description of thermochemical conversion unit}

The fabricated thermochemical conversion unit is consisted of the reactor vessel system and associated supplementary systems for air distribution, biomass feeding and injection, and vapor condensation for bio-oil recovery 
Table 1 Design features of the thermochemical conversion system

\begin{tabular}{l|l}
\hline \multicolumn{1}{c|}{ Major part } & \multicolumn{1}{c}{ Description } \\
\hline Electric motor & $\begin{array}{l}\text { The electric motor served as the driver/prime mover of the thermochemical conversion unit's hopper- } \\
\text { conveyor system. }\end{array}$ \\
\hline Gearbox & $\begin{array}{l}\text { The gearbox facilitated the reduction of the prime mover's speed and, at the same time, increases the } \\
\text { torque. }\end{array}$ \\
\hline Biomass feeding and entry system & $\begin{array}{l}\text { The hopper served as the container of the feedstock to be used during the thermochemical } \\
\text { conversion. The conveyor fed the feedstock to the reactor. The conveyor also facilitated the reduction } \\
\text { of the size of the feedstock. }\end{array}$ \\
\hline Cyclone separator & $\begin{array}{l}\text { The reactor served as the house the feedstock and facilitated the process of thermochemical } \\
\text { conversion. Along with an air distribution system when needed, the feedstock was ignited in the } \\
\text { reactor using a nichrome heater, deprived with oxygen and undergo gasification or pyrolysis, } \\
\text { depending on the heat source. }\end{array}$ \\
\hline Syngas condenser & $\begin{array}{l}\text { The cyclone separators removed the particulates produced during the gasification or pyrolysis } \\
\text { through vortex separation. There are two cyclone separators: the 1D-2D cyclone or low-efficiency } \\
\text { cyclone separator (LECS) and the 1D-3D cyclone or high-efficiency cyclone separator (HECS) adopted } \\
\text { from Parnel (1996) }{ }^{18)}\end{array}$ \\
\hline $\begin{array}{l}\text { The syngas condenser is comprised of a water tank and four condenser canisters. The water tank } \\
\text { contained water or ice to provide the temperature gradient for bio-oil recovery through better } \\
\text { condensation. The four condenser canisters are cylindrical on the upper part and conical at the } \\
\text { bottom to induce the flow of bio-oil down to its catchment by gravity. }\end{array}$ \\
\hline
\end{tabular}

as shown in Fig. 1. The unit included the following major components: electric motor, gearbox, hopper and conveyor, reactor, cyclone separator and syngas condenser.

This newly developed energy conversion system could operate continuously with an initial $8 \mathrm{~kg}$ of full-size corncobs and a reactor capacity of $3 \mathrm{~kg}$ corncob particles with an average size range of $14 \mathrm{~mm}$ to $30 \mathrm{~mm}$. The uniqueness of having a higher capacity conversion system is tantamount to a pilot-scale set up ready for field operation in most farm settings. This development of having such a thermochemical conversion unit makes it more attractive for the farm-level operation to utilize bio-oil, biochar and syngas

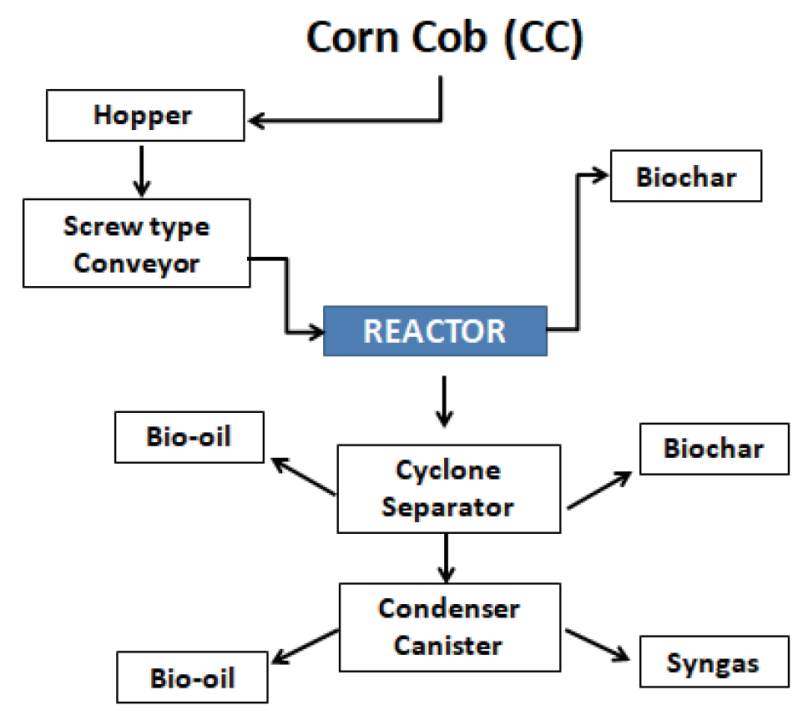

Fig. 1 Schematic diagram for the newly developed thermochemical conversion unit for fuel. Other uses of bio-oil and biochar are common in farming communities such as bio-oil for flavoring of smoked fish and meat, bio-char for soil conditioner, water filter, and fuel briquettes.

\subsection{Testing and evaluation}

Prior to laboratory testing and evaluation, the preliminary test run was conducted to determine each component's functionality. The machine's hopper was filled with $8 \mathrm{~kg}$ of $\mathrm{CC}$ to help maintain pressure in the reactor, while the reactor was filled with $3 \mathrm{~kg}$ of size reduced CC. The experiment utilized three airflow rates and two heating temperatures, as shown in Table 2.

During laboratory testing, the reactor was covered, locked and sealed properly. Ignition of the biomass feedstock was done by turning on the $1 \mathrm{~kW}$ nichrome coil heater for $5 \mathrm{~min}$ and setting the airflow rate of the variable speed drive blower at $10 \mathrm{~Hz}$ for $30 \mathrm{~min}$. Each experimental run requires $90 \mathrm{~min}$ to complete. Once the reactor cooled down, the yields of unburnt cobs, bio-char and bio-oil were then obtained (Fig. 1). Unburnt cobs and bio-char were manually separated carefully, weighed and photographed. The bio-oil yield was obtained by getting the differential of the known weight of the bio-oil catchments to the weight of the bio-oil catchments after each run. The syngas yield was obtained by getting the difference of the starting biomass feedstock ( $3 \mathrm{~kg}$ ) and the sum of the obtained unburnt corn cobs, biochar and bio-oil yields. 
Table 2 Operating conditions in the conducted testing and evaluation

\begin{tabular}{lccc}
\hline \multicolumn{1}{c}{ Variables } & \multicolumn{3}{c}{ Corresponding Code } \\
\hline Heating device usage & \multicolumn{2}{c}{$\mathrm{H}_{\mathrm{w}}$} & $\mathrm{H}_{\circ}$ \\
Equivalent & (with heating device) & (without heating device) \\
\hline Airflow rate & $\mathrm{A}_{1}$ & $\mathrm{~A}_{2}$ & $\mathrm{~A}_{3}$ \\
Equivalent & $38.8 \mathrm{~L} / \mathrm{s}$ & $61.3 \mathrm{~L} / \mathrm{s}$ & $83.8 \mathrm{~L} / \mathrm{s}$ \\
\hline
\end{tabular}

\subsection{Chemical composition and physicochemical properties}

Representative samples were collected for proximate chemical analysis. These sample's proximate chemical analysis was analyzed at STEAG, Inc. (PHIVIDEC Industrial Estate, Villanueva, Misamis Oriental) and Department of Science and Technology - Industrial Technology Development Institute - Standards and Testing Division (DOST-ITDI-STD), DOST Compound, Gen. Santos Ave., Bicutan, Taguig City, Philippines.

\subsection{Calorific value}

The analyses for the heating value of bio-char were carried out following ASTM D-3286. The calorific value of the bio-char was determined using a LECO AC-350 bomb calorimeter. The test was done at the Forest Products Research and Development Institute (FPRDI) of the Department of Science and Technology.

\subsection{Experimental design}

The data gathered was analyzed using two factorial in a complete randomized design. Analysis of Variance (ANOVA) table and the Duncan Multiple Range Test (DMRT) were used to determine the level of significance and comparison among means. Three trials were conducted in each test run.

\section{Results and Discussion}

\subsection{Comminution and feeding rate}

The size reduction of the corn cobs sample was made to make it suitable for thermochemical conversion as it will improve the reaction and increase heat transfer. Table 3 affirms the installed worm gear screw conveyor's capability to reduce raw corn cobs' size, especially its length and thickness. The worm drive screw conveyor reduced the corn cobs' length and thickness by $75.54 \%$ and $51.03 \%$, respectively. The size reduction was brought about by the blades' shearing ability and the small clearance in the pipe between the hopper and the reactor (approx. $1.40 \mathrm{~cm}$ ). The installed worm gear screw conveyor worked like a multiple-fracturing size-reduction implement with the small clearance in the pipe between the hopper and the reactor serving as a screen or diaphragm (Fig. 2). The corn cob feeding rate is approximately $11 \mathrm{~kg} / \mathrm{h}$.
Table 3 Average dimensions of corn cobs using modified worm gear screw conveyor

\begin{tabular}{lcc}
\hline \multicolumn{1}{c}{ Corn Cobs } & $\begin{array}{c}\text { Length } \\
(\mathrm{mm})\end{array}$ & $\begin{array}{c}\text { Thickness } \\
(\mathrm{mm})\end{array}$ \\
\hline Raw Dimension (inside the Hopper) & 129 & 27 \\
Final Dimension (inside the Reactor) & 30 & 14 \\
Size Reduction Difference (\%) & 75 & 51 \\
\hline
\end{tabular}

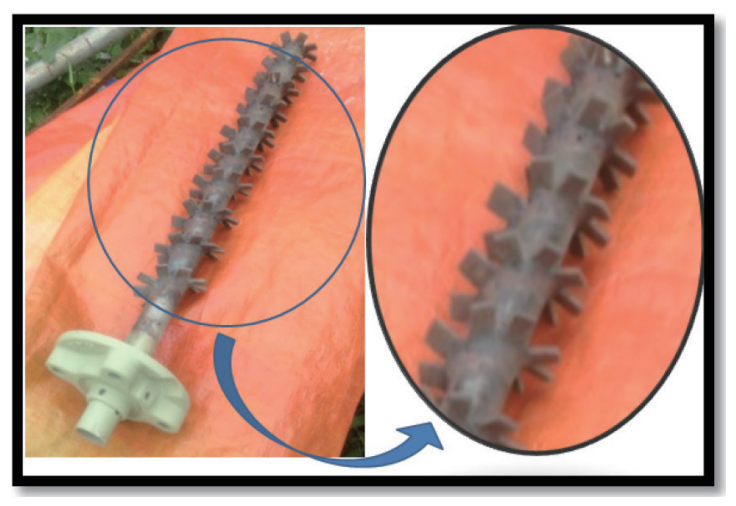

Fig. 2 Size reduction auger

\subsubsection{Unburnt corn cobs}

Table 4 shows the percent recovery of unburnt corn cob from the thermochemical conversion unit. The average percent recovery of unburnt corn cobs at $38 \mathrm{~L} / \mathrm{s}, 61 \mathrm{~L} / \mathrm{s}$ and $84 \mathrm{~L} / \mathrm{s}$ was $12.50 \%, 7.67 \%$ and $4.50 \%$, respectively. However, the average recovery of both with and without a heater was $8.22 \%$. This can be associated with an increase in oxygen content. Consequently, this increases the temperature due to increased activity in the oxidation zone ${ }^{19}$.

\subsubsection{Bio-oil collected from syngas condenser canisters}

Bio-oil is usually dark brown and free-flowing liquids having a distinctively smoky odor. It is composed of very complex mixtures of oxygenated hydrocarbons with a substantial amount of water from both the original moisture and reaction ${ }^{20}$. Table 5 shows the percent bio-oil yield obtained from the syngas condenser canisters after the thermochemical conversion process. The highest obtained bio-oil was $18 \%$ at $84 \mathrm{~L} / \mathrm{s}$ airflow and without heater settings. As the airflow increased, the bio-oil recovery from the syngas condenser canisters also increased. The increase in airflow promotes shorter residence time of the hot vapor, which leads to high liquid production ${ }^{21)}$. Moreover, the gradual increase of the bio-oil yield can be associated with 
Table 4 Recovery of unburnt CC from thermochemical conversion unit, \%

\begin{tabular}{lcccc}
\hline \multirow{2}{*}{ Heating Element } & \multicolumn{3}{c}{ Airflow } & \multirow{2}{*}{ Average } \\
\cline { 2 - 4 } & $38 \mathrm{~L} / \mathrm{s}$ & $61 \mathrm{~L} / \mathrm{s}$ & $84 \mathrm{~L} / \mathrm{s}$ & 8.22 \\
With Heater & $12.00 \pm 0.30$ & $7.33 \pm 0.02$ & $5.33 \pm 0.33$ & 8.22 \\
Without Heater & $13.00 \pm 1.42$ & $8.00 \pm 0.12$ & $3.67 \pm 1.07$ & \\
Average & $12.50^{\mathrm{a}}$ & $7.67^{\mathrm{b}}$ & $4.50^{\mathrm{c}}$ & \\
\hline \multicolumn{2}{l}{ Average or means with the same superscript letters within a column indicate no significant difference $(p<0.05)$}
\end{tabular}

Table 5 Bio-oil collected from syngas condenser canister using thermochemical conversion unit, \%

\begin{tabular}{lcccc}
\hline \multirow{2}{*}{ Heating Element } & \multicolumn{3}{c}{ Airflow } & \multirow{2}{*}{ Average } \\
\cline { 2 - 4 } & $38 \mathrm{~L} / \mathrm{s}$ & $61 \mathrm{~L} / \mathrm{s}$ & $84 \mathrm{~L} / \mathrm{s}$ & 14.33 \\
With Heater & $11.67 \pm 2.92$ & $15.00 \pm 0.18$ & $16.33 \pm 0.52$ & 15.44 \\
Without Heater & $13.00 \pm 0.58$ & $15.33 \pm 1.82$ & $18.00 \pm 0.48$ & \\
Average & $12.33^{\mathrm{a}}$ & $15.17 \mathrm{ab}$ & $17.17^{\mathrm{b}}$ & \\
\hline \multicolumn{2}{l}{ Average or means with the same superscript letters within a column indicate no significant difference $(p<0.05)$}
\end{tabular}

increased reactions during the thermochemical conversion due to the increase in temperature that is more volatiles are produced $^{22)}$.

\subsubsection{Bio-oil collected from cyclone separator}

Table 6 shows the average bio-oil yield obtained from the cyclone separator canisters. The highest obtained bio-oil was $18.67 \%$ at $38 \mathrm{~L} / \mathrm{s}$ airflow and with heater settings. The airflow increases as the amount of bio-oil recovered from the cyclone separators decreases. In the cyclone separator, more bio-oil was produced when using a heater.

\subsubsection{Bio-char}

Bio-char is the solid material obtained from the thermochemical conversion of biomass. It is a fine-grained, highly porous charcoal substance that has been produced by heating organic material under minimal to no oxygen to achieve high surface area per unit volume, thus increasing porosity, high adsorption and minimal residual resin ${ }^{23)}$. Table 7 shows the inverse relationship between the airflow and the amount of bio-char recovery. The highest obtained bio- char was $24 \%$ at $38 \mathrm{~L} / \mathrm{s}$ airflow and without heater settings. The average percent of bio-char recovery of airflows $38 \mathrm{~L} /$ $\mathrm{s}, 61 \mathrm{~L} / \mathrm{s}$ and $84 \mathrm{~L} / \mathrm{s}$ across the heating element are 19\%, $12 \%$ and $6 \%$, respectively. Thus, increasing the airflow decreases bio-char recovery. On the other hand, the percent recoveries across different airflows are 9\% and 16\% with heater and without the heater. The increase in airflow rate brought about a decrease in bio-char recovery by increase in the system's oxygen content. The increased reaction occurs which consequently, increases the yield of volatiles and decrease in bio-char ${ }^{24) \sim 26)}$. Operating without a heater therefore produces higher bio-char than using it.

\subsection{Syngas}

The gaseous fraction among the products of thermochemical conversion is, in general, referred to as synthesis gas (abbreviated as syngas). It is composed of various gases such as $\mathrm{CO}_{2}, \mathrm{CO}, \mathrm{NOx}, \mathrm{SOx}, \mathrm{H}_{2} \mathrm{~S}, \mathrm{H}_{2}$, aldehydes, ketones, volatile carboxylic acids, and gaseous

Table 6 Bio-oil collected from cyclone separator using thermochemical conversion unit, \%

\begin{tabular}{lcccc}
\hline \multirow{2}{*}{ Heating Element } & \multicolumn{3}{c}{ Airflow } & \multirow{2}{*}{ Average } \\
\cline { 2 - 4 } & $38 \mathrm{~L} / \mathrm{s}$ & $61 \mathrm{~L} / \mathrm{s}$ & $84 \mathrm{~L} / \mathrm{s}$ & $17.33^{\mathrm{a}}$ \\
With Heater & $18.67 \pm 1.73$ & $18.00 \pm 1.27$ & $15.33 \pm 0.77$ & $13.56^{\mathrm{b}}$ \\
Without Heater & $16.33 \pm 2.17$ & $12.33 \pm 0.08$ & $12.00 \pm 0.82$ & \\
Average & 17.50 & 10.17 & 13.67 & \\
\hline Average or means with the same superscript letters within a column indicate no significant difference $(p<0.05)$
\end{tabular}

Table 7 Bio-char produced of thermochemical conversion unit, \%

\begin{tabular}{lcccc}
\hline \multirow{2}{*}{ Heating Element } & \multicolumn{3}{c}{ Airflow } & \multirow{2}{*}{ Average } \\
\cline { 2 - 4 } & $38 \mathrm{~L} / \mathrm{s}$ & $61 \mathrm{~L} / \mathrm{s}$ & $84 \mathrm{~L} / \mathrm{s}$ & \\
\hline With Heater & $14.33 \pm 2.87$ & $6.33 \pm 0.15$ & $5.33 \pm 1.38$ & $8.67 \mathrm{a}$ \\
Without Heater & $23.67 \pm 2.77$ & $17.67 \pm 0.22$ & $6.33 \pm 1.88$ & $15.80 \mathrm{~b}$ \\
Average & $19.00^{\mathrm{a}}$ & $12.00^{\mathrm{b}}$ & $5.83^{\mathrm{c}}$ & \\
\hline
\end{tabular}

Average or means with the same superscript letters within a column indicate no significant difference $(p<0.05)$ 
hydrocarbons ${ }^{27)}$. Table 8 shows that the highest obtained syngas was $59 \%$ at $84 \mathrm{~L} / \mathrm{s}$ airflow and without heater settings. As the airflow increased, the syngas yield increased. The syngas yield values were computed to be the difference of the biomass feedstock fed to the system and the sum of the obtained bio-oil, unburnt cobs, and bio-char.

\subsection{Characteristics of bio-char}

Tables 9 and 10 show the proximate and ultimate analysis of bio-char yields from thermochemical conversion runs under different operating parameters. The proximate and ultimate analysis was undertaken to assess the biochar's suitable application as a potential fuel source. In terms of fixed carbon, operating with a heater produces a slightly higher composition than without a heater. Ash percentage also increased when the heater was used in operation hence promoting possible combustion inside the reactor.

Bio-char samples subjected to proximate analysis were mixtures of the bio-char produced from each replicate for each treatment. The sample was approximately bonedry due to the temperature inside the reactor reaching $500^{\circ} \mathrm{C}$. On the other hand, the ultimate analysis shown in Table 10 portrays the increase in bio-char's carbon element compared to the raw corn cobs. Such an increase in carbon leads to an increase in heating value which is a very important fuel consideration.

\subsection{Mass and energy balance}

The energy generated by corn cob wastes was characterized in different phases such as bio-char, biooil and syngas. Syngas energy in most biomass materials is primarily a combination of combustible gasses like methane, carbon monoxide and hydrogen gas. In the study of Capareda et al. ${ }^{28}$, average syngas produced has $20 \% \mathrm{H}_{2}$, $10 \% \mathrm{CH}_{4}$ and $15 \% \mathrm{CO}$ by volume at Standard Temperature and Pressure (STP). Such gasses $\mathrm{H}_{2}, \mathrm{CH}_{4}$ and $\mathrm{CO}$ have heating values of $142 \mathrm{MJ} / \mathrm{kg}, 55.5 \mathrm{MJ} / \mathrm{kg}$ and $10.1 \mathrm{MJ} / \mathrm{kg}$, respectively. However, Zainal et al. ${ }^{29)}$ found a heating value of 4-6 MJ/ $\mathrm{Nm}^{3}$. Using the heating values of corn cob byproducts in Table 11, the mass and energy balance can be depicted below in Fig. 3. Losses from unburned corncobs and ashes could be avoided if the system is fully insulated to maintain a uniform temperature inside the reactor.

With the newly developed energy conversion system, the energy stored in the corn cob could not balance the energy output. However, ashes and unburned corncobs could be utilized in different beneficial ways. Thus, the system's efficiency is computed below, which shows a $91 \%$ waste to energy conversion.

Table 8 Syngas produced of thermochemical conversion 5unit, \%

\begin{tabular}{lcccc}
\hline \multirow{2}{*}{ Heating Element } & \multicolumn{3}{c}{ Airflow } & \multirow{2}{*}{ Average } \\
\cline { 2 - 4 } & $38 \mathrm{~L} / \mathrm{s}$ & $61 \mathrm{~L} / \mathrm{s}$ & $84 \mathrm{~L} / \mathrm{s}$ & $50.87 \mathrm{a}$ \\
With Heater & $43.30 \pm 7.67$ & $52.50 \pm 0.80$ & $56.80 \pm 0.80$ & $46.16 \mathrm{~b}$ \\
Without Heater & $34.00 \pm 1.43$ & $45.50 \pm 1.63$ & $59.00 \pm 0.48$ & \\
Average & $38.65^{\mathrm{a}}$ & $49.00^{\mathrm{b}}$ & $57.90^{\mathrm{c}}$ & \\
\hline \multicolumn{2}{l}{ Average or means with the same superscript letters within a column indicate no significant difference $(p<0.05)$}
\end{tabular}

Table 9 Proximate analysis of bio-char from the thermochemical conversion unit

\begin{tabular}{lcccc}
\hline \multicolumn{2}{c}{ Parameters } & $\begin{array}{c}\text { Volatile combustible matter, } \\
\%\end{array}$ & $\begin{array}{c}\text { Ash, } \\
\%\end{array}$ & $\begin{array}{c}\text { Fixed carbon, } \\
\%\end{array}$ \\
\hline \multirow{2}{*}{ Without } & A1-38.8 L/s & 40.17 & 4.46 & 55.37 \\
Heater & A2-61.3 L/s & 26.89 & 5.94 & 67.17 \\
& A3-83.8 L/s & 33.56 & 6.23 & 60.21 \\
\multirow{2}{*}{ With } & A1-38.8 L/s & 27.06 & 10.41 & 62.53 \\
Heater & A2-61.3 L/s & 25.98 & 6.51 & 67.51 \\
& A3-83.8 L/s & 35.20 & 6.53 & 58.97 \\
\hline
\end{tabular}

Table 10 Comparison of the elemental properties of corn cobs and bio-char (\% wt.)

\begin{tabular}{ccc}
\hline Elemental Component & Corn Cobs & Bio-char \\
\hline C & 41.15 & 57.56 \\
H & 4.93 & 2.33 \\
O & 37.40 & 7.18 \\
N & 0.18 & 0.86 \\
S & 0.04 & 0.31 \\
\hline
\end{tabular}

Table 11 Comparison of heating values of corn cob and its byproducts

\begin{tabular}{lc}
\hline \multicolumn{1}{c}{ Sample } & Heating value $(\mathrm{MJ} / \mathrm{kg})$ \\
\hline Bio-char & 26.3 \\
Corn Cobs (air-dried) & 17.5 \\
Bio-Oil & 26.3 \\
Syngas & 10.9 \\
\hline
\end{tabular}




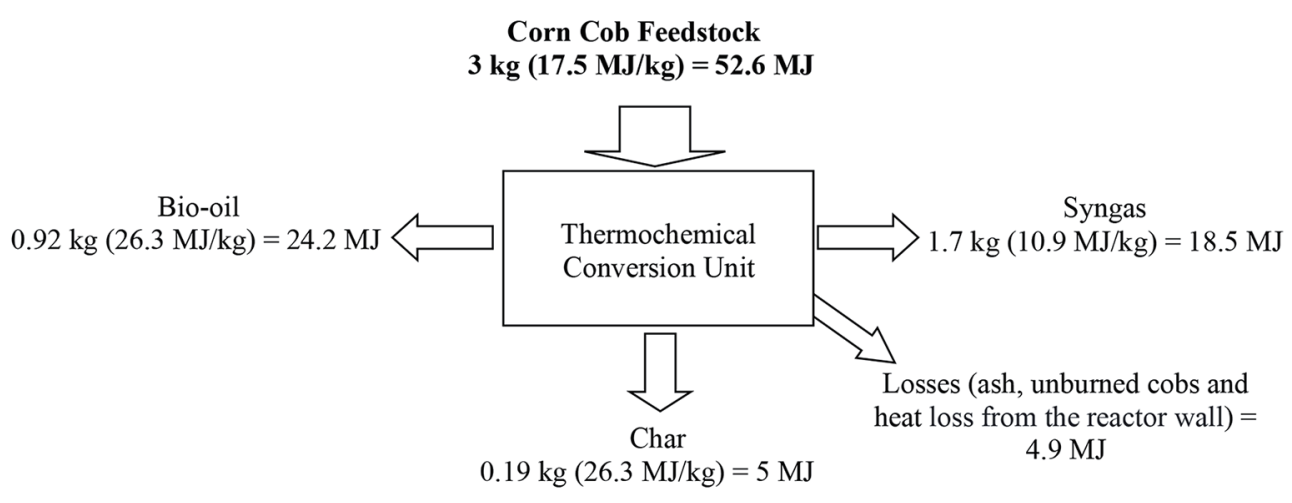

Fig. 3 Energy and mass balance for the newly developed thermochemical conversion unit

$$
\begin{aligned}
& \text { Conversion Efficiency = Energy Output / Energy Input } \\
& \qquad \begin{aligned}
& \{1.7 \mathrm{~kg}(10.0 \mathrm{MJ} / \mathrm{kg})+0.92 \mathrm{~kg}(26.3 \mathrm{MJ} / \mathrm{kg}) \\
& +0.19 \mathrm{~kg}(26.3 \mathrm{MJ} / \mathrm{kg})\} /\{3 \mathrm{~kg}(17.5 \mathrm{MJ} / \mathrm{kg})\} \\
& =(47.9 \mathrm{MJ}) /(52.6 \mathrm{MJ}) \\
& =91 \%
\end{aligned}
\end{aligned}
$$

\section{Conclusions}

A thermochemical conversion unit with a condensing unit for corn residues was designed, fabricated and tested. It consisted of a hopper, modified worm drive, reactor, cyclones separator and syngas condenser. The design incorporated a unique feature that automatically breaks the whole corncob into smaller particles with 50 to $75 \%$ size reduction while conveying the feedstock. The study is so unique that all corncob sizes from corn shelling operation could be reduced by 75\% upon passing through the newly developed worm gear screw conveyor. This mechanism is such of novelty that it combines particle size reduction and conveyance operation. Therefore, such a mechanism eliminates the need for hammer milling or shredding, thus saving time and energy. Moreover, the system could be operated continuously at $3 \mathrm{~kg}$ reactor capacity and a standby hopper capacity of $8 \mathrm{~kg}$.

The highest percentages of biochar, bio-oil and syngas collected using the developed machine were 24\%, 37\% and $59 \%$. Bio-char contains 33\% of volatile combustible matter, $60 \%$ of fixed carbon and a heating value of $26.3 \mathrm{MJ} / \mathrm{kg}$. To achieve the highest percent recoveries of bio-oil and syngas, the machine should be operated at an airflow of $84 \mathrm{~L} / \mathrm{s}$. On the other hand, to obtain the highest recovery of bio-char, the unit should be operated at lower airflow. The machine has a waste to energy conversion efficiency that could reach as high as $91 \%$.

\section{References}

1) Chang, J. et al., Biomass and Bioenergy, 39, 67-72 (2011)

2) Wander, P. R. et al., Biomass and Bioenergy, 27, 467-476 (2004)
3) International Energy Agency Bioenergy Task 32 report, FINAL REPORT: Status overview of torrefaction technologies, Enschede, 2012

4) University of California Riverside, Technology Evaluation and Economic Analysis of Waste Tire Pyrolysis, Gasification, and Liquefaction, California Integrated Waste Management Board, 2006

5) Sokhansanj, S.; Turhollow, A. F., Applied Engineering in Agriculture, 18, 525-530 (2002)

6) Gallagher et al., "Biomass from Crop Residues: Some Social Cost and Supply Estimates for U.S. Crops," Staff General Research Papers Archive 5124, Iowa State University, Department of Economics, (2003)

7) Perlack, R. D.; Turhollow, A. F., Energy, 28, 1395-1403 (2003)

8) Petrolia, D. R., Biomass and Bioenergy, 32, 603-612 (2008)

9) Turhollow, A. F.; Sokhansanj, S., Applied Engineering in Agriculture, 23, 439-48 (2007)

10) Gustafson, C. R.; Maung, T. A.; Saxowsky, D.; Nowatzki, J.; Miljkovic, T., Economics of Sourcing Cellulosic Feedstock for Energy Production, Available at http:// ageconsearch.umn.edu/handle/103260, (2011)

11) Larson, E. D., Biofuel production technologies: status, prospects and implications for trade and development, United Nations Conference on Trade and Development, 2008

12) Lau, F. S.; Bowen, D. A.; Dihu, R.; Doong, S.; Hughes, E. E.; Remick, R.; Slimane, R.; Turn, S. Q.; Zabransky, R., Techno-economic analysis of hydrogen production by gasification of biomass, Final technical report for the period 15 September 2001-14 September 2002, contract DE-FC36-01GO11089 for United States Department of Energy, Gas Technology Inst., Des Plaines, IL, June (rev.): 145, (2003)

13) Childress, J.; Childress R., World gasi cation survey: a preliminary evaluation. Proceedings of the Gasi cation Technologies Conference, San Francisco, 2004

14) Williams R. H.; Larson, E. D.; Jin, H., Comparing 
climate-change mitigating potentials of alternative synthetic liquid fuel technologies using biomass and coal. Proceedings of the Fifth Annual Conference on Carbon Capture and Sequ, 2006

15) Pastoors, H., The Willem Alexander Centrale, Haelen, the Netherlands, 2006

16) Milne T. A.; Agblevor, F.; Davis, M.; Deutch, S.; Johnson, D., Developments in Thermochemical Biomass Conversion, A Review of Chemical Composition of Fast Pyrolysis Oils, Blackie Academic \& Professional, London, 1997

17) Cubio, G. M.; Chavez, A. T.; Ravanera, R., Biomass Energy from Agricultural Wastes: A Potential Solution to Power Crisis in Northern Mindanao, 11th International Agricultural Engineering Conference and Exhibition, 64th PSAE Annual National Convention, 25th Agricultural Engineering Week. Conference Proceedings and Book of Abstracts. pp. 72., ISSN: 23628227, 2014

18) Parnell, C.B. Jr., Cyclone Design For Air Pollution Abatement Associated With Agricultural Operations, Proceedings of the 1996 Beltwide Cotton Production Conferences. National Cotton Council. Nashville, TN., 1996

19) Mohammed, I. Y.; Abakr, Y. A.; Kazi, F. K.; Yusuf, S.;
Alsharef, I.; Soh, A. C., Bio-resources, 10(4), 6457e6478 (2015)

20) Qi, Z.; Jie, C.; Tiejun, W.; Ying, X., Energy Conversion and Management, 48, 87-92 (2007)

21) Bridgewater, A. V., Journal of Analytical and Applied Pyrolysis, 51(1-2), (1999)

22) Ali, N.; Saleem M.; Shahzad K.; Rana M., Journal of Pakistan Institute of Chemical Engineers, 42(2),79-86 (2014)

23) Hunt, J., Duponte, M., Sato, D.; Kawabata, A., The Basics of Biochar: A Natural Soil Amendment. College of Tropical Agriculture and Human Resources, The University of Hawai'i at Manoa, SCM-30, 1-6 (2010)

24) Li et al., BioRes., 11(2), 3259-3274 (2016)

25) Sorgonà et al., Procedia - Social and Behavioral Sciences, 223, $871-878$ (2016)

26) Yadav, K.; Jagadevan, S., Influence of Process Parameters on Synthesis of Biochar by Pyrolysis of Biomass: An Alternative Source of Energy, IntechOpen, DOI: 10.5772/intechopen.88204, (2019)

27) Verma et al., International Journal of Chemical Engineering, 2012, Article ID 542426, 18 pages, (2012)

28) Capareda, C., Introduction to Biomass Energy Conversions, CRC Press, 2013

29) Zainal, Z. A.; Rifau, A.; Quadir, G. A.; Seetharamu, K. N., Biomass and Bioenergy, 23(4), 283-289 (2002) 